\begin{tabular}{|c|c|}
\hline MAR 251999 ENGINEERING DATA TRANSMITTAL & 1. edr $62622 \frac{1}{44}$ \\
\hline
\end{tabular}

\begin{tabular}{|l|l|}
\hline $\begin{array}{l}\text { 2. To: (Receiving Organization); } \\
\text { Distribution }\end{array}$ & $\begin{array}{l}\text { 3. From: (Originating Organization) } \\
\text { HANDI } 2000\end{array}$ \\
\hline 5. Proj./Prog./Dept./Div.: & $\begin{array}{l}\text { 6. Design Authority/Design Agent/Cog. Engr.: } \\
\text { HANDI } 2000\end{array}$ \\
\hline Scott I. Bennion \\
\hline
\end{tabular}

8. Originator Remarks:

For Release.

Keywords: HANDI 2000, Master Equipment List, PassPort, H2K, Work Mgmt

11. Receiver Remarks:

11A. Design Baseline Document? $\bigcirc$ Yes

No
4. Related EDT No.:
N/A
7. Purchase Order No.:
$\mathrm{N} / \mathrm{A}$
9. Equip./Component No.:
N/A

10. System/Bldg./Facility:

N/A.

12. Major Assm. Dwg. No.:

$\mathrm{N} / \mathrm{A}$

13. Permit/Permit Application No.:

N/A.

14. Required Response Date:

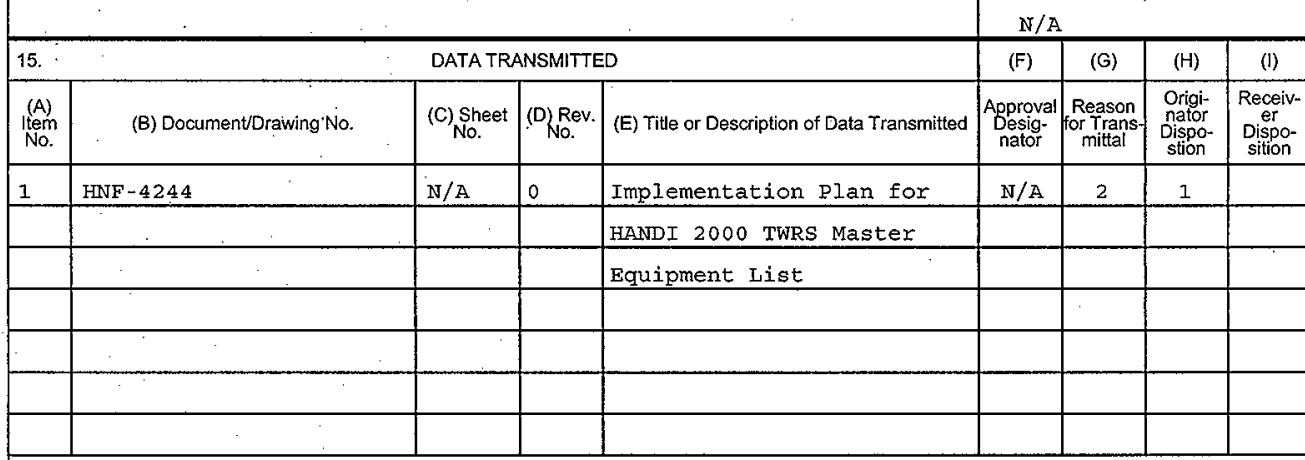

16.

KEY

\begin{tabular}{|c|}
\hline Approval Designator (F) \\
\hline $\begin{array}{c}\text { E, S, } Q, D Q R N / A \\
\text { (See WHC-CM-3-5, } \\
\text { Sec. 12.7) }\end{array}$ \\
\hline
\end{tabular}

17.

\begin{tabular}{|}
\hline \\
\hline \\
\hline \\
\hline \\
\hline
\end{tabular}
Reason for Transmittal (G)

4. Review

5. Post-Review

6. Dist. (Receipt Acknow. Required)

SIGNATURE/DISTRIBUTION

SIGNATUREIDISTRIBUTION

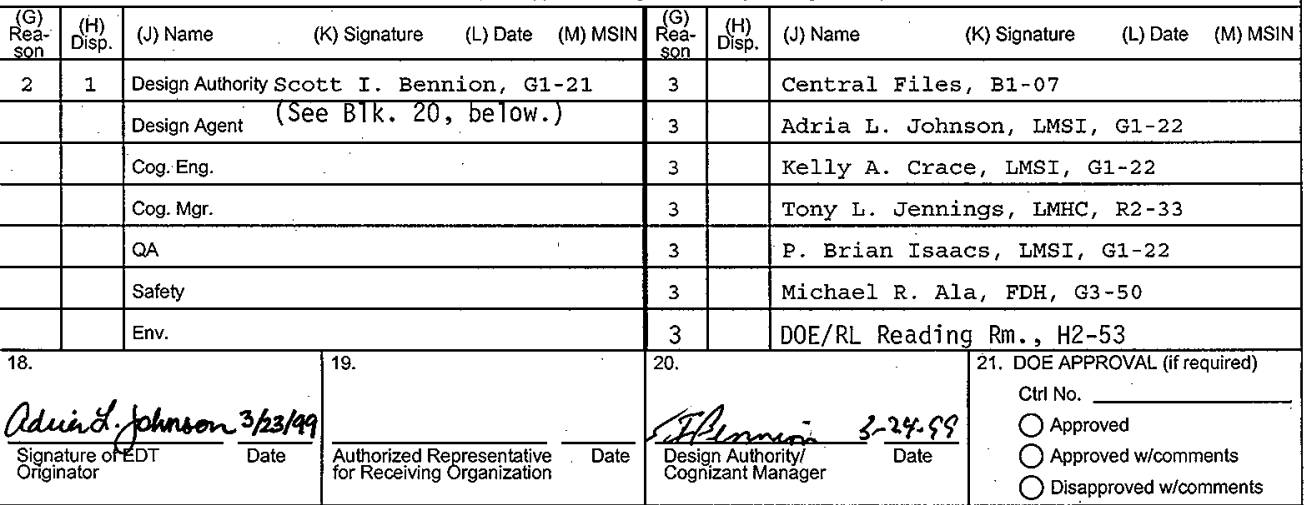




\title{
IMPLEMENTATION PLAN FOR HANDI 2000 TWRS MASTER EQUIPMENT LIST
}

\author{
Scott I. Bennion, Fluor Daniel Hanford Company
}

2355 Stevens Drive, MSIN G1-21

Richland, WA 99352

U.S. Department of Energy Contract DE-AC06-96RL13200

$\begin{array}{lllll}\text { EDT/ECN: } 626244 & \text { UC: } 900 & & \\ \text { Org Code: } & 48000 & \text { Charge Code: } 105755 & \text { AA30 } & \text { HN9F0401 } \\ \text { B\&R Code: } & \text { Ew7001000 } & \text { Total Pages: } 2 T_{\text {ga }} 22 & \end{array}$

Key Words: HANDI 2000, Master Equipment List, PassPort, H2K, Work Mgmt

Abstract:

This document presents the implementation plan for an additional deliverable of the HANDI 2000 Project. The Passport Equipment Data module processes include those portions of the COTS PassPort system required to support tracking and management of the Master Equipment List for Lockheed Martin Hanford Company (LMHC) and custom software created to work with the coTs products.

TRADEMARK DISCLAIMER. Reference herein to any specific commercial product, process, or service by trade name, trademark, manufacturer, or otherwise, does not necessarily constitute or imply its endorsement, recommendation, or favoring by the United States Government or any agency thereof or its contractors or subcontractors.

Printed in the United States of America. To obtain copies of this document, contact: Document Control Services, P.O. Box 950, Mailstop H6-08, Richland WA 99352, Phone (509) 372-2420; Fax (509) 376-4989.

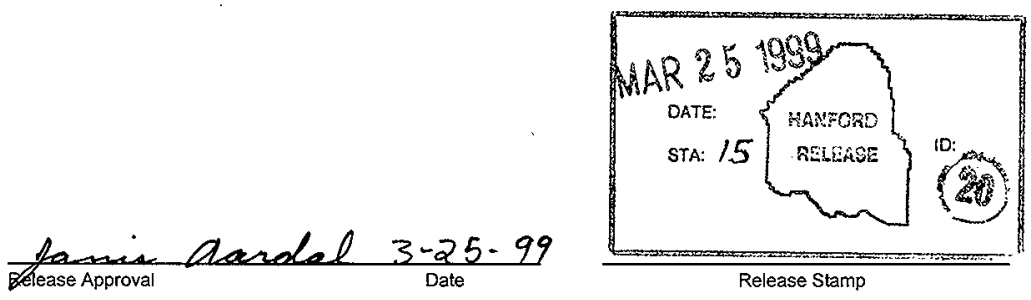




\section{IMPLEMENTATION PLAN}

FOR

HANDI 2000

TWRS MASTER EQUIPMENT LIST

Prepared by: Adria L. Johnson, Systems Analyst Lockheed Martin Services, Inc.

Prepared for: Fluor Daniel Hanford

Approved by:
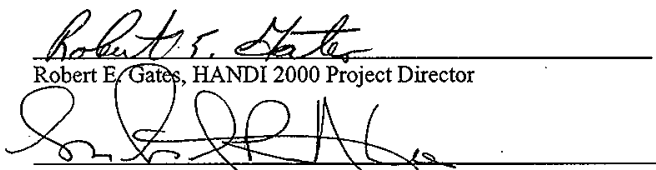

Michael R. Ala, HAND<2000 Operations \& Maintenance Manager

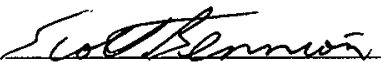

Scott I. Bennion, HANDI 2000 Project Manager

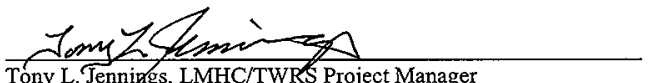

Tony L. Tennings, LMHC/TWRS Project Manager

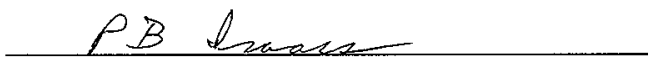

Phillip B. (Brian) Isaacs, LMSI Project Manager

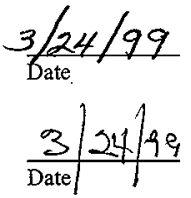

$\frac{3-24-59}{\text { Date }}$

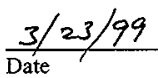

$\frac{3 / 23 / 99}{\text { Date }}$ 


\section{TABLE OF CONTENTS}

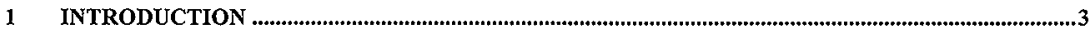

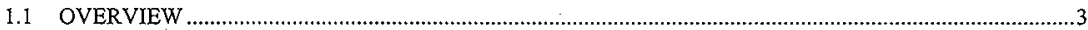

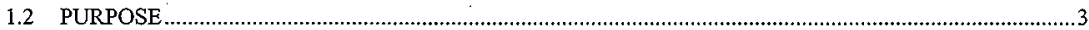

1.3 SCOPE

1.4 DOCUMENTATION CROSSWALK

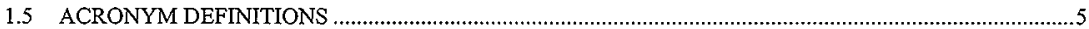

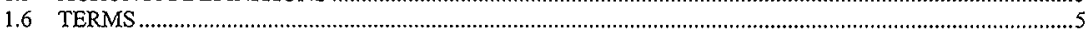

2 IMPLEMENTATION OVERVIEW

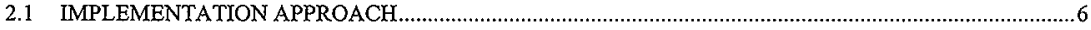

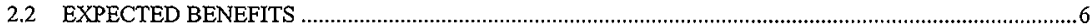

2.3 PROCESSES TO BE IMPLEMENTED

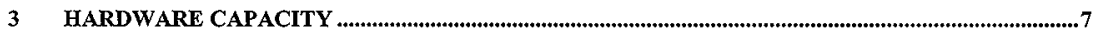

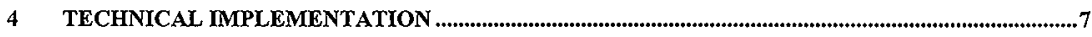

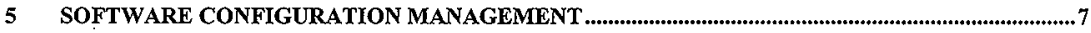

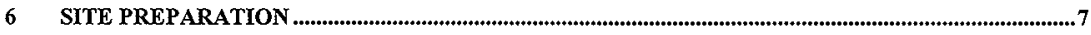

$7 \quad$ SYSTEM ADMINISTRATION AND SUPPORT

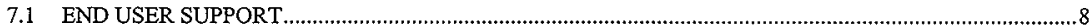

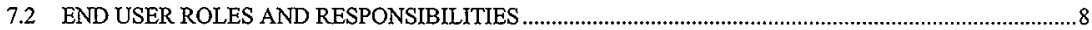

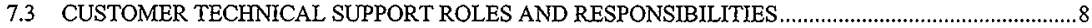

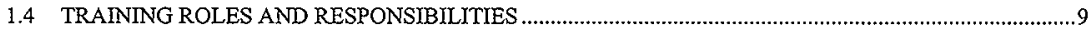

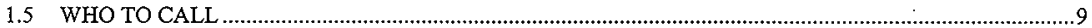

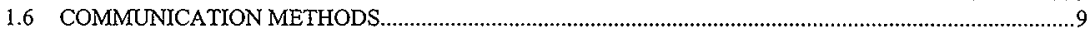

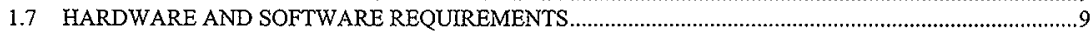

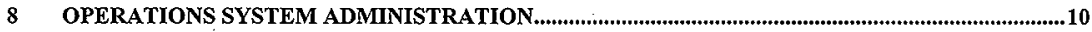

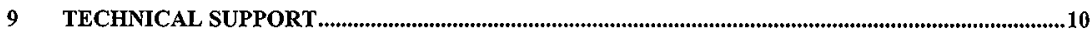

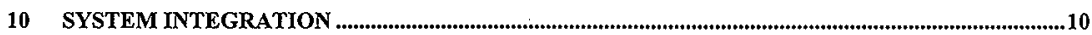

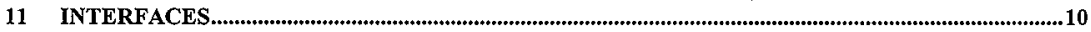

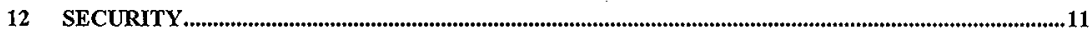

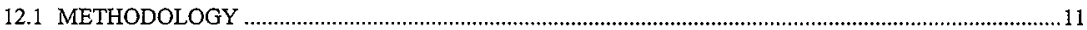

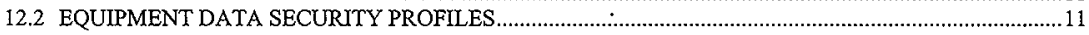

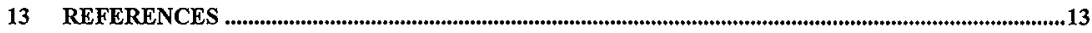

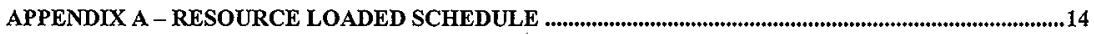




\section{INTRODUCTION}

\subsection{OVERVIEW}

The Hanford Data Integration 2000 (HANDI 2000) Project is an integrated and comprehensive set of functional applications containing core information necessary to support the Project Hanford Management Contract (PHMC). It is based on the Commercial-Off-The-Shelf (COTS) product solution with commercially proven business processes. The system reduces the number of legacy systems maintained today and absorbs key systems identified that have Year 2000 issues. This includes systems that support finance, supply and chemical management/Material Safety Data Sheet (MSDS), human resources and payroll activities on the Hanford Site. The PASSPORT' ${ }^{1}$ software is an integrated application for Accounts Payable, Contract Management, Inventory Management, Purchasing, and MSDS. The PeopleSoft ${ }^{2}$ software is an integrated application for General Ledger, Project Costing, Human Resources, Payroll, Benefits, and Training. The implementation of this set of products was the first deliverable of the HANDI 2000 Project and is referred to as Business Management System (BMS) and Chemical Management/MSDS.

This document presents the implementation plan for an additional deliverable of the HANDI 2000 Project. The PASSPORT TM Equipment Data module processes include those portions of the COTS PASSPORT ${ }^{\text {TM }}$ system required to support tracking and management of the Master Equipment List for Lockheed Martin Hanford Company (LMHC) and custom software created to work with the COTS products.

\subsection{PURPOSE}

The primary objective of this implementation plan is to communicate the methods and schedule for implementation and roll out to end users of Equipment Data.

\subsection{SCOPE}

This implementation plan addresses the implementation strategy for the Equipment Data. The implementation plan includes sections on the following:

- Implementation Overview

- Hardwate Capacity

- Technical Implementation

- Software Configuration Management

- Site Preparation

- System Administration and Support

- System Integration

- Interfaces

- Security

- Resource Loaded Schedule

1 PASSPORT is a tradematk of INDUS International, San Francisco, California.

2 PeopleSoft is a trademark of PeopleSoft Inc, Pleasanton, California 


\subsection{DOCUMENTATION CROSSWALK}

INDUS Abacus methodology documentation recommends a number of plans to be created for implementation of their products. This implementation plan for Equipment Data will follow these recommendations. This implementation plan will refer to existing BMS documentation to satisfy the recommended plans, when applicable. The following table provides a crosswalk between the existing BMS documentation and the plans recommended by the Abacus methodology.

\begin{tabular}{|c|c|c|c|c|c|c|c|c|c|c|c|c|}
\hline \multirow[b]{2}{*}{$\begin{array}{l}\text { Plans Recommended by } \\
\text { Abacus Methodology }\end{array}$} & \multicolumn{12}{|c|}{ Existing BMS Documentation } \\
\hline & 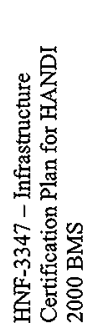 & 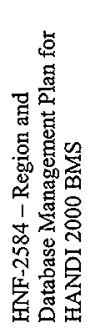 & 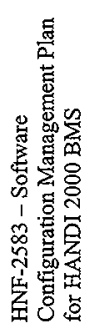 & 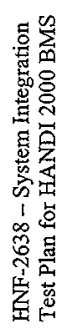 & 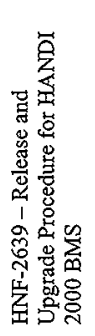 & 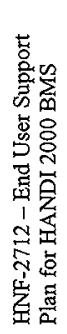 & 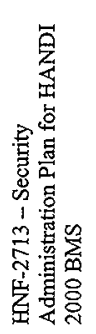 & 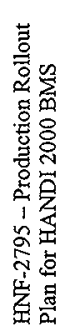 & 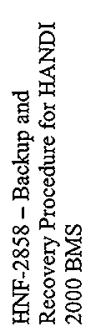 & 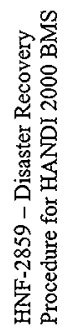 & 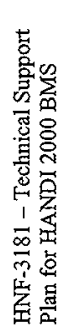 & 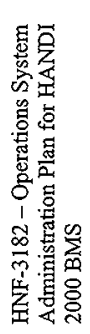 \\
\hline Hardware Capacity Plan & $\mathrm{X}$ & & & & & & & & & & & \\
\hline $\begin{array}{l}\text { Technical Implementation } \\
\text { Plan }\end{array}$ & & & & & & & & $\mathrm{X}$ & & & & \\
\hline $\begin{array}{l}\text { Software Configuration } \\
\text { Management Plan }\end{array}$ & & & $\mathrm{X}$ & & & & & & & & & \\
\hline Site Preparation Plan & $\mathrm{X}$ & & & & & $x^{\circ}$ & & $\mathrm{X}$ & & & & \\
\hline $\begin{array}{l}\text { System Administration and } \\
\text { Support Plan }\end{array}$ & & $\mathrm{X}$ & & & $\mathrm{x}$ & $\mathrm{X}$ & & & $\mathrm{X}$ & $X$ & $\mathrm{X}$ & $\mathrm{X}$ \\
\hline System Integration Plan & & & & $X$ & & & & & & & & \\
\hline \multicolumn{13}{|l|}{ Interface Plan* } \\
\hline Security Plan & & & & & & & $\mathrm{X}$ & & & & & \\
\hline
\end{tabular}

* Equipment Data does not interface with any systems external to PASSPORT ${ }^{\mathrm{TM}}$, therefore no documents are mapped to the listed Interface Plan. 


\subsection{ACRONYM DEFINITIONS}

\begin{tabular}{|l|l|}
\hline \multicolumn{1}{|c|}{ Acronym } & \multicolumn{1}{c|}{ Definition } \\
\hline BMS & Business Management System \\
\hline COTS & Commercial-Off-The-Shelf \\
\hline CTS & Customer Technical Support \\
\hline ECN & Engineering Change Notice \\
\hline FDH & Fluor Daniel Hanford, Incorporated \\
\hline HANDI 2000 & Hanford Data Integrator 2000 \\
\hline HLAN & Hanford Local Area Network \\
\hline HUH & Hanford User Help \\
\hline LMHC & Lockheed Martin Hanford Company \\
\hline LMSI & Lockheed Martin Services, Incorporated \\
\hline MSDS & Material Safety Data Sheet \\
\hline PHMC & Project Hanford Management Contract \\
\hline TWRS & Tank Waste Remediation System \\
\hline Y2K & Year 2000 \\
\hline
\end{tabular}

\subsection{TERMS}

Database: The disk space set-aside for storing information in tables.

HANDI 2000 Project: The Hanford Data Integration 2000 Project is an integrated comprehensive set of functional applications containing core information needed to support the Project Hanford Management Contract.

Fardware: Physical equipment used in data processing, as opposed to computer programs, procedures, rules, and associated documentation.

Interface: (1) A shared boundary. (2) To interact or communicate with another system component.

Module: (1) A program unit that is discrete and identifiable with respect to compiling, combining with other units and loading. (ANSI). (2) A logically separable part of a program.

Program: A computer program.

Requirement: (1) A condition or capability needed by a user to solve a problem or achieve an objective. (2) A condition or capability that must be met by a system or system component to satisfy a contract, standard, specification, or other formally imposed document. The set of all requirements forms the basis for subsequent development of the system or system component.

Software: Computer programs, procedures, rules, and associated documentation and data pertaining to the operation of a computer system. 


\section{IMPLEMENTATION OVERVIEW}

\subsection{IMPLEMENTATION APPROACH}

- The Master Equipment List implementation will ensure that the data and information priorities for the necessary aspects of the Equipment Data are established

- The Equipment Data implementation will use and build upon the PHMC infrastructure and technology developed to meet PHMC-specific requirements

- COTS and Site Data Standards will be used to promote interoperability, extensibility, and capability for evolution

\subsection{EXPECTED BENEFITS}

- Simplification

- Streamlined processing

- Error reduction

- Standardized processes

- Improved access to information by utilizing the drilldown functionality

- Process and function ownership

- Reduction in the number of systems to maintain

- Reduction in number of redundant data sources

- True integrated processing between systems

- One place to go for item descriptions

- Template structure will assist in description consistency

- Elimination of duplicate entry (for all of the replaced data sources)

- Improved system history of problem actions and resolutions

- Provides fundamental data required for continued progress in Work Management systems 


\subsection{PROCESSES TO BE IMPLEMENTED}

Processes to be implemented include maintenance of new equipment records, existing equipment records, temporary installations, and additional details as available. For additional information, reference 1998INNTX-S1766-0998-a, Rev. 0.0, PassPort Application TWRS Work Flow Analysis Report Consisting of: Work Management, Preventive Maintenance, Materials, and Equipment.

\section{HARDWARE CAPACITY}

The hardware parameters established for BMS will also be used for Equipment Data. No changes are needed for this implementation. Refer to HNF-3347, Revision 0, Infrastructure Certification Plan for HANDI 2000 Business Management System.

\section{TECHNICAL IMPLEMENTATION}

Implementation of enterprise-wide software has a potential impact on many areas of the Information Systems structure. During the BMS project, Indus provided a site survey that identified the technical requirements of, and potential technical impediments to, a successful implementation. The survey examined the present and planned network, desktop hardware and software strategy, existing server capacity, and technical skill sets of employees working to implement and maintain the system for BMS and anticipated Work Management implementation activities. All issues were addressed during the BMS implementation. The addition of the Equipment Data is within the scope of the original site survey.

\section{SOFTWARE CONFIGURATION MANAGEMENT}

No changes to the current BMS PASSPORT ${ }^{\mathrm{MM}}$ software configuration management process are required during the implementation of Equipment Data. Refer to HNF-2583, Revision 1, Software Configuration Management Plan for HANDI 2000 Business Management System.

\section{SITE PREPARATION}

Site preparation activities were performed during the implementation of BMS. Refer to HNF-2795, Revision $\dot{0}$, Production Roll Out Plan for HANDI 2000 Business Management System, HNF-3347, Revision 0, Infrastructure Certification Plan for HANDI 2000 Business Management System, and HNF-2712, Revision 0, End User Support Plan for HANDI 2000 Business Management System. Equipment Data will follow processes established during the implementation of BMS. 


\section{SYSTEM ADMINISTRATION AND SUPPORT}

\subsection{END USER SUPPORT}

End user support processes were defined as a part of BMS Implementation. Refer to HNF-2712, Revision 0, End User Support Plan for HANDI 2000 Business Management System.

The primary objective of the End User Support Plan is to ensure that the end users have access that is reasonable and commensurate with job position functionality in order to perform their work effectively. Another objective was to ensure user support was provided to utilize the new BMS while minimizing significant security risks to BMS. The BMS End User Support Plan became effective with the document's acceptance and will provide guidance through future implementation efforts and, as a "living document", will support the operations and maintenance of HANDI 2000 systems.

This document encompassed and standardized the integrated approach for end user support for the BMS and future HANDI 2000 systems. It also identified the support methods to be used.

\subsection{END USER ROLES AND RESPONSIBILITIES}

End users are the application users of the HANDI 2000 systems. They are responsible for reporting any problems they incur with the HANDI 2000 applications.

\subsubsection{Training}

End users will be trained according to their user level and business need prior to being given access to any of the HANDI 2000 application production regions.

\subsection{CUSTOMER TECHNICAL SUPPORT ROLES AND RESPONSIBILITIES}

Customer Technical Support (CTS) will be fielding user calls. CTS will be handling general user questions and will be provided a list of contacts for Equipment Data.

\subsubsection{Customer Technical Support Training}

A PASSPORT ${ }^{\text {TM }}$ overview training session was held for CTS personnel prior to the implementation of BMS.

\subsubsection{Points Of Contacts}

A list of Equipment Data points of contact names will be provided to CTS. The lists will be comprised of names of primary business and technical points of contact. These individuals will provide PASSPORT ${ }^{\mathrm{TM}}$ patrol functions during the rollout of Equipment Data. Refer to HNF-3440, Revision 0, Patrol Plan for HANDI 2000 Business Management System.

\subsubsection{Hanford User Help Information}

Hanford User Help (HUH) information will be collected for Equipment Data and Bill of Materials. This information will be added to the PASSPORT ${ }^{\mathrm{TM}}$ section of HUH.

The HUH homepage is located at http://www.rl.gov:1050/huh/findex.htm. 


\subsection{TRAINING ROLES AND RESPONSIBILITIES}

Equipment Data training will be informal. End users are encouraged to complete the PASSPORT TM Computer Based Training. Informal overview training sessions that will be given by the implementation team to small groups of power users.

End users will also be provided an intranet on-line help guide for the Master Equipment List. The intranet on-line help will provide a menu of functions and describes the step by step process to complete the function in PASSPORTTM.

\subsection{WHO TO CALL}

Refer to the following matrix for whom to call with questions regarding Equipment Data implementation.

\begin{tabular}{|l|l|}
\hline \multicolumn{1}{|c|}{ Type of Questions } & \multicolumn{1}{c|}{ Who to Call } \\
\hline Business questions & Tony Jennings, LMHC, 373-3447 \\
\hline Computer application system questions & Kelly Crace, LMSI, 373-0361 \\
\hline General logging on and printing questions & Customer Technical Support (CTS), 376-1234 \\
\hline
\end{tabular}

\subsection{COMMUNICATION METHODS}

Communication to the End Users is accomplished in a variety of ways including, but not limited to:

- Informational Sessions provided to planners and engineers

- Emails and bulletins

- Hanford Reach articles.

- Weekly reports to management

\subsection{HARDWARE AND SOFTWARE REQUIREMENTS}

\subsubsection{Minimum Work Station Requirements}

All Equipment Data users are considered to be Power Users, as defined in HNF-2712, Revision 0, End User Support Plan for HANDI 2000 Business Management System. The minimum work station tequirements for power users are listed below:

- PASSPORT ${ }^{\mathrm{TM}}$ Client Workstation

- Pentium 100 Processor

- 32 MB RAM

- $60 \mathrm{MB}$ Available Disk Space

- Windows 95 or Windows 98

- Portal/97 PAssPoRT ${ }^{\mathrm{TM}}$ Interface 6.1.1

As organizations procure new workstations they should refer to the site standards for new purchases.

\subsubsection{Software}

In addition to the above software on client workstations, End users must have Hanford Local Area Network (HLAN) access. Software Distribution WinInstall Hanford Site Applications will be used to download the appropriate software for PASSPORT TM to the client workstation. 


\section{OPERATIONS SYSTEM ADMINISTRATION}

Equipment Data will follow established processes for operations system administration, as described in $\mathrm{HNF}-3180$, Revision 0, Operations System Administration Plan for HANDI 2000 Business Management System.

\section{TECHNICAL SUPPORT}

Equipment Data will follow established processes for technical support, as described in HNF-3181, Revision 0, Technical Support Plan for HANDI 2000 Business Management System.

\section{SYSTEM INTEGRATION}

The Master Equipment List implementation activates the Equipment Data process embedded within the PASSPORT ${ }^{\mathrm{TM}}$ product. All functionality provided is integrated within that product and requires no additional integration with external applications.

\section{INTERFACES}

System interfaces provide data transfer between multiple computer systems. Equipment Data does not interface with any systems external to PASSPORT ${ }^{\mathrm{TM}}$. 


\section{SECURITY}

\subsection{METHODOLOGY}

PASSPORT ${ }^{\text {TM }}$ security methods described in HNF-2713, Revision 0, Security Administration Plan for HANDI 2000 Business Management System, will be used for Equipment Data.

\subsection{EQUIPMENT DATA SECURITY PROFILES}

The following user responsibility descriptions are defined for the purposes of initial implementation. These descriptions are subject to change as needed by business process changes.

\subsubsection{User Responsibility Descriptions}

Read Only - Users who need to view PASSPORT ${ }^{\mathrm{TM}}$ for purposes of receiving information that helps them in their day to day jobs.

Labeling Group - Users responsible for the assignment of equipment identification numbers, walking down and validating field configuration and updating of essential drawings at TWRS.

Equipment Engineer - Users responsible for the preventive maintenance program information. Assignment of proper references and validity of the equipment information in the Master Equipment List. Changing of the status of equipment.

Cognizant Engineer - Users providing verification of Bills of Materials and Material Request approval when a Bill of Materials is not identified for a piece of equipment. Cognizant Engineers perform input into PASSPORT ${ }^{\mathrm{TM}}$ of equipment records for new equipment, modifications in the field, and temporary installed equipment.

Planner-Users of equipment records in developing material requests and the planning of work. Uses the equipment records to determine approved models and verify references applicable to the equipment.

Design Engineer - Users performing input of all available information for new equipment that is part of their design but not already installed in the field into PASSPORT ${ }^{\text {TM }}$ equipment records for new equipment.

Nuclear Engineer-Users performing input of relevant Safety Equipment List information into the PASSPORTTM equipment records.

Quality Assurance - Users that review and approve quality information in the Bill of Materials for equipment and for Material Requests that are developed when a Bill of Materials is not available for a piece of equipment.

Environmental Engineer - Users responsible for inputting the Pollution Code and percent for applicable equipment into the PASSPORT ${ }^{\mathrm{TM}}$ Equipment records.

Equipment Administrator - Users that modify code tables for equipment data as required to support the continued improvement of the Master Equipment List. 


\subsubsection{User Profile Descriptions}

The following table defines panel access for each user role:

\begin{tabular}{|c|c|c|c|c|c|c|c|c|c|c|}
\hline Panel & 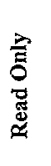 & 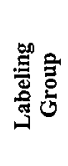 & 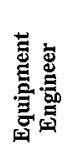 & 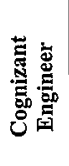 & 䉥 & 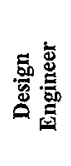 & 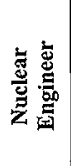 & 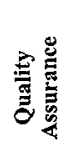 & 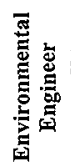 & 总嘧 \\
\hline Material Request & $\mathrm{X}$ & $\mathrm{X}$ & $\mathrm{X}$ & $\mathrm{X}$ & $\mathrm{X}$ & $\mathrm{X}$ & $\mathrm{X}$ & $\mathrm{X}$ & $\mathrm{X}$ & $\mathrm{X}$ \\
\hline Material Request Detail & $\mathrm{X}$ & $\mathrm{X}$ & $\mathrm{X}$ & $\mathrm{X}$ & $\mathrm{X}$ & $\mathrm{X}$ & $\mathrm{X}$ & & & $\mathrm{X}$ \\
\hline Model Based M/R Generation & & & $\mathrm{X}$ & $\mathrm{X}$ & & & & & & $\mathrm{X}$ \\
\hline M/R Catalog Item Substitutes & $\mathrm{X}$ & $\mathrm{X}$ & $\mathrm{X}$ & $\mathrm{X}$ & $\mathrm{X}$ & $\mathrm{X}$ & $X$ & $\mathrm{X}$ & $\mathrm{X}$ & $\mathrm{X}$ \\
\hline Material Request List & $\mathrm{X}$ & $\mathrm{X}$ & $\mathrm{X}$ & $\mathrm{X}$ & $\mathrm{X}$ & $\mathrm{X}$ & $\mathrm{X}$ & $\mathrm{X}$ & $\mathrm{X}$ & $\mathrm{X}$ \\
\hline Material Request Qty Status & $\mathrm{X}$ & $\mathrm{x}$ & $\mathrm{X}$ & $\mathrm{X}$ & $\mathrm{X}$ & $\mathrm{X}$ & $\mathrm{X}$ & $\mathrm{X}$ & $\mathrm{X}$ & $\mathrm{X}$ \\
\hline M/R List by Work Order & $\mathrm{X}$ & $\mathrm{X}$ & $\mathrm{X}$ & $\mathrm{X}$ & $\mathrm{X}$ & $\mathrm{X}$ & $\mathrm{X}$ & $\mathrm{X}$ & $\mathrm{X}$ & $\mathrm{X}$ \\
\hline Equipment Lists & $\mathrm{X}$ & $\mathrm{X}$ & $\mathrm{X}$ & $\mathrm{X}$ & $\mathrm{X}$ & $\mathrm{X}$ & $\mathrm{X}$ & $\mathrm{X}$ & $\mathrm{X}$ & $\mathrm{X}$ \\
\hline Work Item Data & $\mathrm{X}$ & $x$ & $\mathrm{X}$ & $\mathrm{X}$ & $\mathrm{X}$ & $\mathrm{X}$ & $\mathrm{X}$ & $\mathrm{X}$ & $\mathrm{X}$ & $\mathrm{X}$ \\
\hline Operational Unit Data & $\mathrm{X}$ & $\mathrm{X}$ & $\mathrm{X}$ & $\mathrm{X}$ & $\mathrm{X}$ & $\mathrm{X}$ & $\mathrm{X}$ & $\mathrm{X}$ & $\mathrm{X}$ & $\mathrm{X}$ \\
\hline Equipment Component Header & $\mathrm{X}$ & $\mathrm{X}$ & $\mathrm{X}$ & $\mathrm{X}$ & $\mathrm{X}$ & $\mathrm{X}$ & $\mathrm{X}$ & $\mathrm{X}$ & $\mathrm{X}$ & $\mathrm{X}$ \\
\hline Uniquely Tracked Commodity & $\mathrm{X}$ & $\mathrm{X}$ & $\mathrm{X}$ & $\mathrm{X}$ & $\mathrm{X}$ & $\mathrm{X}$ & $\mathrm{X}$ & $\mathrm{X}$ & $\mathrm{X}$ & $\mathrm{X}$ \\
\hline Facility Operation Status & $\mathrm{X}$ & $\mathrm{X}$ & $\mathrm{X}$ & $\mathrm{X}$ & $\mathrm{X}$ & $\mathrm{X}$ & $\mathrm{X}$ & $\mathrm{X}$ & $\mathrm{X}$ & $X$ \\
\hline Unit Out of Service History & $\mathrm{X}$ & $\mathrm{X}$ & $\mathrm{X}$ & $\mathrm{X}$ & $\mathrm{X}$ & $\mathrm{X}$ & $\mathrm{X}$ & $\mathrm{X}$ & $\mathrm{X}$ & $X$ \\
\hline Equip/Component/UTC Parameters & $\mathrm{X}$ & $\mathrm{X}$ & $\mathrm{X}$ & $\mathrm{X}$ & $\mathrm{X}$ & $\mathrm{X}$ & $\mathrm{X}$ & $\mathrm{X}$ & $\mathrm{X}$ & $\mathrm{X}$ \\
\hline Equipment History Summary & $\mathrm{X}$ & $\mathrm{X}$ & $\mathrm{X}$ & $\mathrm{X}$ & $\mathrm{X}$ & $\mathrm{X}$ & $\mathrm{X}$ & $\mathrm{X}$ & $\mathrm{X}$ & $\mathrm{X}$ \\
\hline Equipment Group ID Data & $\mathrm{X}$ & $\mathrm{X}$ & $\mathrm{X}$ & $\mathrm{X}$ & $\mathrm{X}$ & $\mathrm{X}$ & $\mathrm{X}$ & $\mathrm{X}$ & $\mathrm{X}$ & $\frac{\mathrm{X}}{x y}$ \\
\hline Equipment Group ID List & $\mathrm{X}$ & $\mathrm{X}$ & $\mathrm{X}$ & $\mathrm{X}$ & $\mathrm{X}$ & $\mathrm{X}$ & $\mathrm{X}$ & $\mathrm{X}$ & $\mathrm{X}$ & $\bar{X}$ \\
\hline BOM Where Used Analysis & $\mathrm{X}$ & $\mathrm{X}$ & $\mathrm{X}$ & $\mathrm{X}$ & $\mathrm{X}$ & $\mathrm{X}$ & $\mathrm{X}$ & $\mathrm{X}$ & $\mathrm{X}$ & $\mathrm{X}$ \\
\hline Bill of Materials & $\mathrm{X}$ & $\mathrm{X}$ & $\mathrm{X}$ & $\mathrm{X}$ & $X$ & $\mathrm{X}$ & $\mathrm{X}$ & $\mathrm{X}$ & $\mathrm{X}$ & $\mathrm{X}$ \\
\hline Master Materials Catalog & $\mathrm{X}$ & $\mathrm{x}$ & $\mathrm{X}$ & $\mathrm{X}$ & $\mathrm{X}$ & $\mathrm{X}$ & $\mathrm{X}$ & $\mathrm{X}$ & $\mathrm{X}$ & $\mathrm{X}$ \\
\hline Material Classification & $\mathrm{X}$ & $x$ & $\mathrm{X}$ & $\mathrm{X}$ & $\mathrm{X}$ & $\mathrm{X}$ & $\mathrm{X}$ & $\bar{X}$ & $\mathrm{X}$ & $\mathrm{X}$ \\
\hline New Item Initiation & $\mathrm{X}$ & $\mathrm{X}$ & $\mathrm{X}$ & $\mathrm{X}$ & $\mathrm{X}$ & $\mathrm{X}$ & $\mathrm{X}$ & $\mathrm{X}$ & $\mathrm{X}$ & $\mathrm{X}$ \\
\hline UTC Materials Trace Summary & $\mathrm{X}$ & $\mathrm{X}$ & $\mathrm{X}$ & $\mathrm{X}$ & $\mathrm{X}$ & $\mathrm{X}$ & $\mathrm{x}$ & $\mathrm{X}$ & $\mathrm{X}$ & $\mathrm{X}$ \\
\hline UTC Materials Trace History & $\mathrm{X}$ & $\mathrm{X}$ & $\mathrm{X}$ & $\mathrm{X}$ & $\mathrm{X}$ & $\mathrm{X}$ & $\mathrm{X}$ & $\mathrm{X}$ & $\mathrm{X}$ & $x$ \\
\hline System Code Maintenance & & & $\mathrm{X}$ & $\mathrm{X}$ & & & & & & $\mathrm{X}$ \\
\hline Division Code Maintenance & & & $\mathrm{X}$ & $\mathrm{X}$ & & & & & & $x$ \\
\hline Area Code Maintenance & & & $\mathrm{X}$ & $\mathrm{X}$ & & & & & & $\mathrm{X}$ \\
\hline Equipment Type Maintenance & & & $\mathrm{X}$ & $\mathrm{X}$ & & & & & & $\mathrm{X}$ \\
\hline Equipment Sub Type Maintenance & & & $\mathrm{X}$ & $\mathrm{X}$ & & & & & & $\mathrm{X}$ \\
\hline Equipment Hierarchy Maintenance & & & $\mathrm{X}$ & $\mathrm{X}$ & & & & & & $\mathrm{x}$ \\
\hline Location ID Requirements & & & $\mathrm{X}$ & $x$ & & & & & & $\mathrm{X}$ \\
\hline
\end{tabular}




\section{REFERENCES}

Evosevich, Sandra, and Terri M. Lutter, 1998, Software Configuration Management Plan for HANDI 2000 Business Management System, HNF-2583, Rev. 1, Lockheed Martin Services Inc., for Fluor Danie1 Hanford, Inc., Richland, Washington.

Kuyper, Thomas, 1998a, Infrastructure Certification Plan for HANDI 2000 Business Management System, HNF3347, Rev. 0, Lockheed Martin Services Inc., for Fluor Daniel Hanford, Inc., Richland, Washington.

Kuyper, Thomas, 1998b, Operations System Administration Plan for HANDI 2000 Business Management System, HNF-3182, Lockheed Martin Services Inc., for Fluor Daniel Hanford, Inc., Richland, Washington.

Kuyper, Thomas, 1998c, Technical Support Plan for HANDI 2000 Business Management System, HNF-3181, Lockheed Martin Services Inc., for Fluor Daniel Hanford, Inc., Richland, Washington.

Maiden-Lowe, Christine, 1998, Patrol Plan for HANDI 2000 Business Management System, HNF-3440, Rev. 0, Lockheed Martin Services Inc., for Fluor Daniel Hanford, Inc., Richland, Washington.

McKay, Amanda, 1998a, Production Roll Out Plan for HANDI 2000 Business Management System, HNF-2795, Rev. 0, Lockheed Martin Services Inc., for Fluor Daniel Hanford, Inc., Richland, Washington.

McKay, Amanda, 1998b, End User Support Plan for HANDI 2000 Business Management System, HNF-2712, Rev. 0, Lockheed Martin Services Inc., for Fluor Daniel Hanford, Inc., Richland, Washington.

McKay, Amanda, 1998c, Security Administration Plan for HANDI 2000 Business Management System, HNF-2713, Rev. 0, Lockheed Martin Services Inc., for Fluor Daniel Hanford, Inc., Richland, Washington.

1998, PassPort Application TWRS Work Flow Analysis Report Consisting of: Work Management, Preventive Maintenance, Materials, and Equipment, 1998IINTX-S-1766-0998-a, Rev. 0.0, Indus International, for Lockheed Martin Hanford Company, Richland Washington. 


\section{APPENDIX A - RESOURCE LOADED SCHEDULE}

The attached resource loaded schedule for HANDI 2000 Work Management, dated March 22, 1999, includes three phases. This implementation plan is applicable to phase one only. Phase one includes Equipment Data installation in PASSPORT ${ }^{\mathrm{TM}}$. 


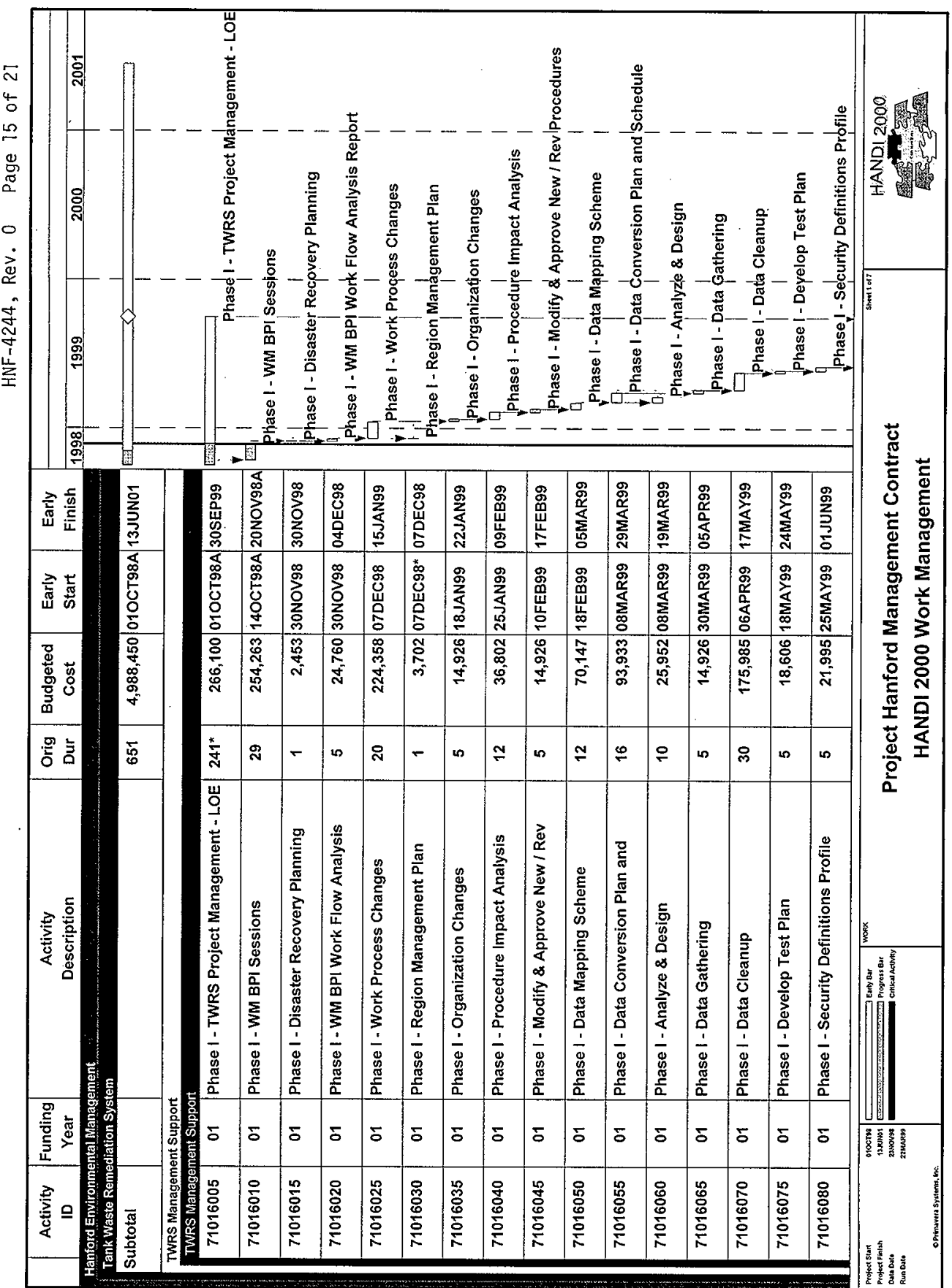


HNF -4244 , Rev. 0 Page 16 of 21

\begin{tabular}{|c|c|c|c|c|c|c|c|c|}
\hline \multirow{2}{*}{$\begin{array}{l}\text { Activity } \\
\text { ID }\end{array}$} & \multirow{2}{*}{$\begin{array}{c}\text { Funding } \\
\text { Year }\end{array}$} & \multirow{2}{*}{$\begin{array}{c}\text { Activity } \\
\text { Description }\end{array}$} & \multirow{2}{*}{$\begin{array}{l}\text { Orig } \\
\text { Dur }\end{array}$} & \multirow{2}{*}{$\begin{array}{l}\text { Budgeted } \\
\text { Cost }\end{array}$} & \multirow{2}{*}{$\begin{array}{l}\text { Early } \\
\text { Start }\end{array}$} & \multirow{2}{*}{\begin{tabular}{|c|c|} 
Early \\
Finish \\
\end{tabular}} & \multirow[b]{2}{*}{\begin{tabular}{|l|}
1998 \\
\end{tabular}} & \multirow[b]{2}{*}{1999} \\
\hline & & & & & & & & \\
\hline & 01 & Phase I - Test Security & 1 & 1,963 & 02JUN99 & 02JUN99 & & Phase I - Test Security \\
\hline 71016090 & 01 & Phase I - Develop Test Data \& Scripts & 8 & 46,353 & O3JUN99 & 14JUN99 & 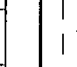 & Phase I - Develop Test Data \& Scripts \\
\hline 71016095 & 01 & Phase I - Load Manual Data to Production & 40 & 172,144 & 15JUN99 & 11AUG99 & 1 & Phase I- Load Manual Data to Production \\
\hline 71016100 & 01 & Phase I - Load Data To Test & 4 & 7,211 & 15JUN99 & 18JUN99 & i & Load Data To Test \\
\hline 71016105 & 01 & Phase I - Implement New Work Processes & 5 & 17,402 & 21JUN99 & 25JUN99 & $\begin{array}{l}1 \\
1\end{array}$ & Phase I - Implement New Work|Processes \\
\hline 71016110 & 01 & Phase I - Load Acceptance Region \& Verify & 5 & 2,453 & 28JUN99 & 02.JUL99 & $i$ & Phase I - Load Acceptance Region \& Verify \\
\hline 71016115 & 01 & Phase I - Quality Assessment Go No-Go & 2 & 6,952 & 07JUL99 & 08JUL99 & 1 & Phase I - Quality Assessment Go No-Go \\
\hline 71016120 & 01 & Phase I-Issue Procedures & 1 & 388 & 09JUL99 & 09JUL99 & 1 & Phase I- | Issue Procedures | \\
\hline 71016125 & 01 & Phase I - Load Static Data to Production & 3 & 6,188 & 12AUG99 & 16AUG99 & 1 & Phase I-Load Static Data to Production \\
\hline 71016130 & 01 & Phase I - Load Active Data to Production & 1 & 5,654 & 17AUG99 & 17AUG99 & 1 & | 1 Phase I-Load Active Data to Production \\
\hline 71016135 & 01 & $\begin{array}{l}\text { Phase I - Production Cut-over - Equipment } \\
\text { Data }\end{array}$ & 1 & 1,653 & 18AUG99 & 18AUG99 & 1 & Phase I - Production Cut-over -Equipment Data \\
\hline 71016140 & 01 & Phase I - Integration Application Testing & 24 & 121,901 & 19AUG99 & 22SEP99 & 1 & asé I - Integration Applícation Testing \\
\hline 71016145 & 01 & Phase I - Stress Testing & 5 & 4,906 & 23SEP99 & 29SEP99 & 1 & se I-Stress Testing | \\
\hline 71016A1M & 01 & $\begin{array}{l}\text { Phase I - TWR 6.3.2 Master Equipment List } \\
\text { Comple }\end{array}$ & 0 & 0 & & 30SEP99* & 1 & Phase I - TWR 6.3.2 Master Equipment List Comple \\
\hline 71016155 & 02 & $\begin{array}{l}\text { Phase I - Integration and Configuration } \\
\text { Testing }\end{array}$ & 12 & 85,182 & $010 \mathrm{CT} 99$ & $180 \mathrm{CT} 99$ & i & Phase 1 - Integration and Configuration Testing \\
\hline 71016205 & 02 & Phase II - TWRS Project Management & $158^{*}$ & 144,462 & $010 C T 99$ & 02JUN00 & 1 & Phase 11 - TWRS Project Management \\
\hline 71016160 & 02 & Phase 1-Performance Tuning & 10 & 5,222 & $190 \mathrm{CT} 99$ & 01NOV99 & 1 & Pháse I - Performance Tiuning \\
\hline 71016210 & 02 & $\begin{array}{l}\text { Phase II - Prepare Road Show (Business } \\
\text { Changes) }\end{array}$ & 3 & 3,438 & 09NOV99 & 11NOV99 & 1 & Phase 11 - Prepare Road Show (Business Changes) \\
\hline 71016215 & 02 & Phase II - Disaster Recovery Planning & 5 & 9,576 & O9NOV99 & 15NOV99 & 1 & Phase II - Disaster Recbvery Planning \\
\hline 71016220 & 02 & $\begin{array}{l}\text { Phase II - Present Road Show (Business } \\
\text { Changes) }\end{array}$ & 32 & 13,212 & 12NOV99 & 18JAN00 & $\begin{array}{l}1 \\
1\end{array}$ & Phase II - Preșent Road Show (Buşiness Changes) \\
\hline 71016225 & 02 & Phase II - Procedure Impact Analysis & 10 & 45,804 & 16 NOV99 & 06DEC99 & 1 & Phase II - Procedure Impact Analysis \\
\hline
\end{tabular}




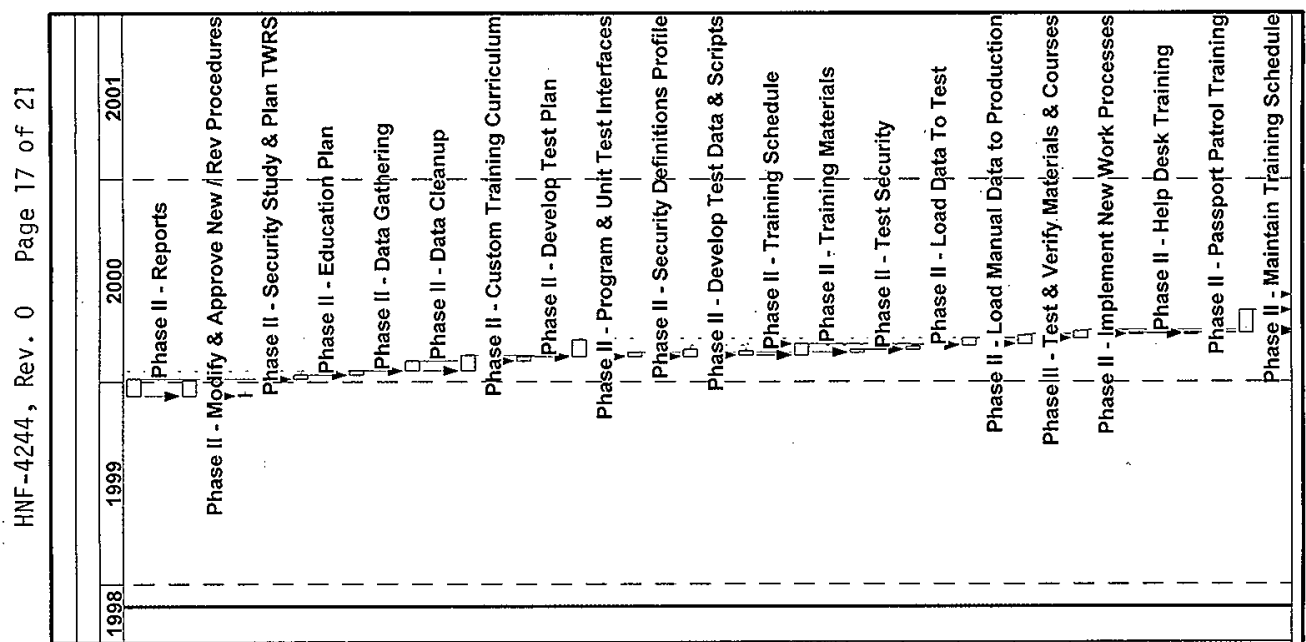

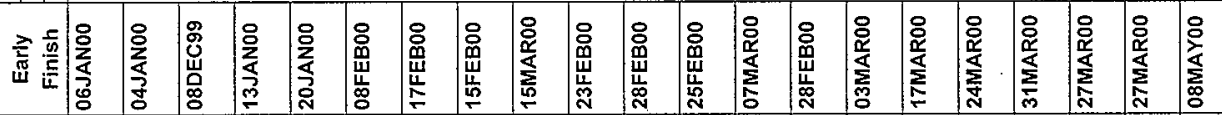

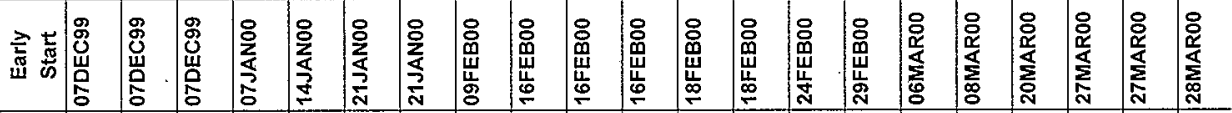

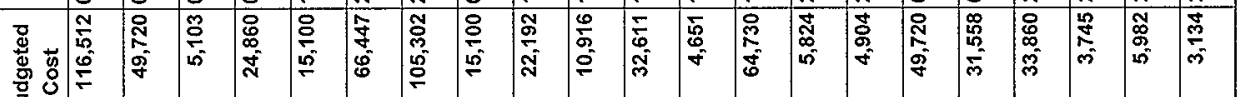
䔰

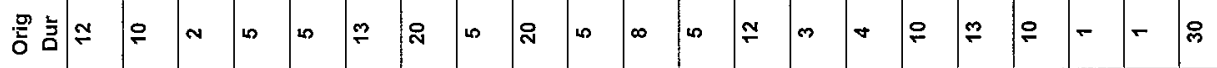

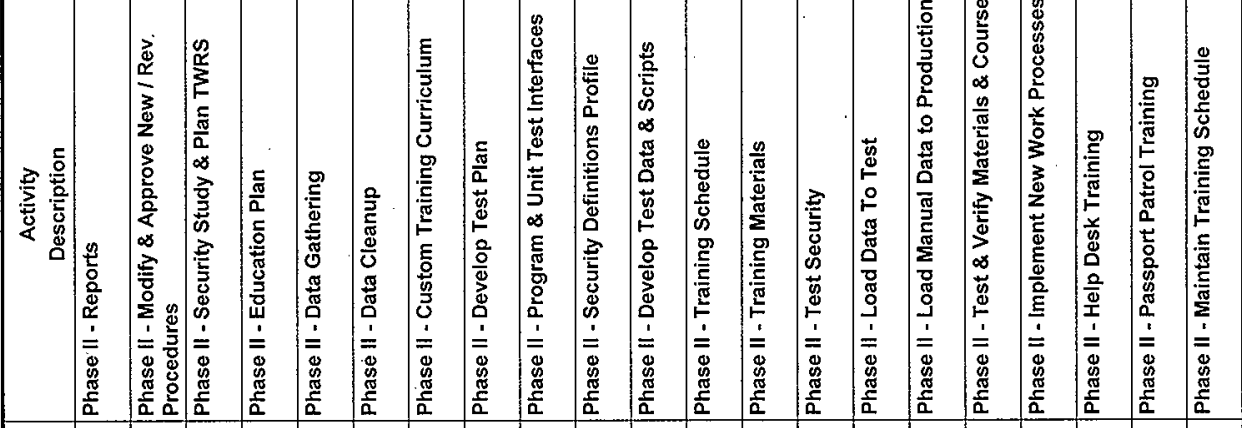

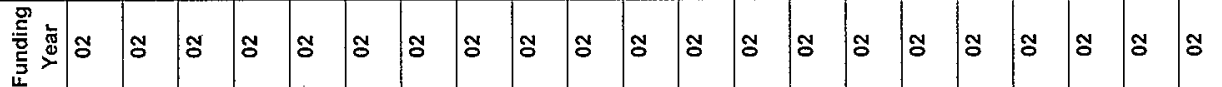

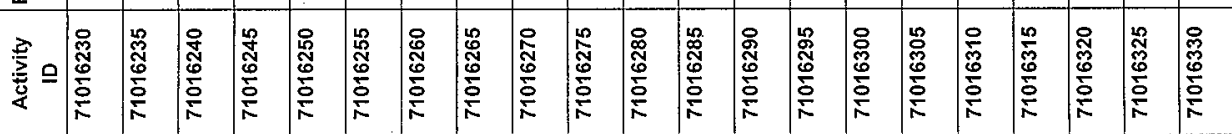


HNF-4244, Rev. 0 Page 18 of 21

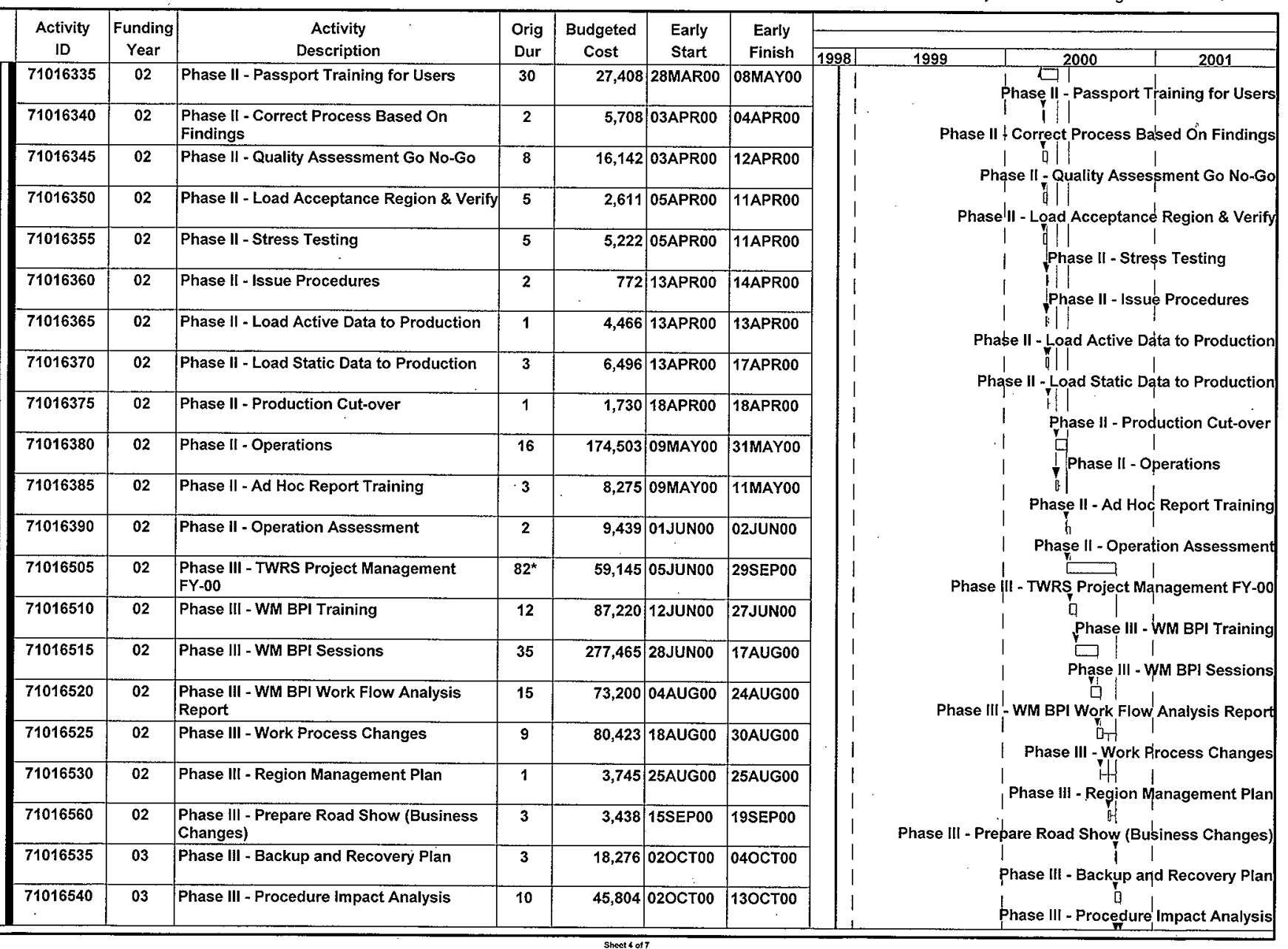


HNF-4244, Rev. 0 Page 19 of 21

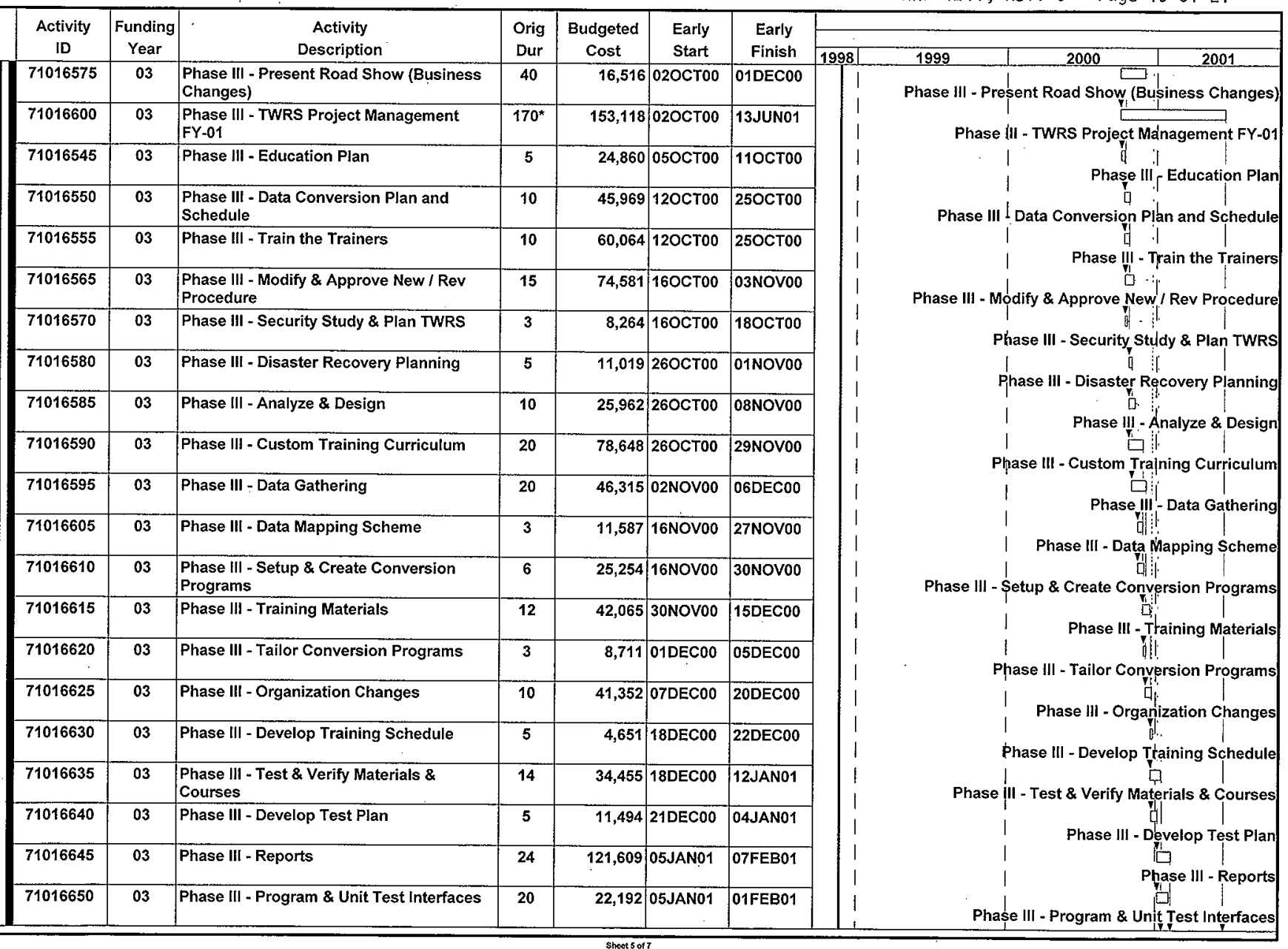


HNF-4244, Rev. 0 Page 20 of 21

\begin{tabular}{|c|c|c|c|c|c|c|c|c|}
\hline \multirow{2}{*}{$\begin{array}{l}\text { Activity } \\
\text { ID }\end{array}$} & \multirow{2}{*}{$\begin{array}{c}\text { Funding } \\
\text { Year }\end{array}$} & \multirow{2}{*}{$\begin{array}{c}\text { Activity } \\
\text { Description }\end{array}$} & \multirow{2}{*}{$\begin{array}{l}\text { Orig } \\
\text { Dur }\end{array}$} & \multirow{2}{*}{$\begin{array}{l}\text { Budgeted } \\
\text { Cost }\end{array}$} & \multirow{2}{*}{$\begin{array}{l}\text { Early } \\
\text { Start }\end{array}$} & \multirow{2}{*}{$\begin{array}{l}\text { Early } \\
\text { Finish }\end{array}$} & \multicolumn{2}{|c|}{\begin{tabular}{|ll} 
\\
\end{tabular}} \\
\hline & & & & & & & \begin{tabular}{|l|}
1998 \\
\end{tabular} & \begin{tabular}{|l|l|l|}
1999 & 2000 & 2001 \\
\end{tabular} \\
\hline 71016655 & 03 & Phase III - Maintain Training Schedule & 50 & 5,224 & 15JAN01 & 26MAR01 & & Phase III - Maintain Training Schedule \\
\hline 71016660 & 03 & Phase III - Help Desk Training & 2 & 7,491 & 15JAN01 & 16JAN01 & | & Phase III - Help Desk Training \\
\hline 71016665 & 03 & Phase III - Passport Training for Users & 50 & 68,520 & 15JAN01 & 26MAR01 & 1 & Phase III - Passport Training for Users \\
\hline 71016670 & 03 & Phase III - Data Cleanup & 10 & 41,211 & 08FEB01 & 22FEB01 & 1 & Phase III Data Cleanup \\
\hline 71016675 & 03 & Phase III - Develop Test Data \& Scripts & 8 & 30,239 & 08FEB01 & 20FEB01 & 1 & Phase III - Develop Test Data \& Scripts \\
\hline 71016680 & 03 & Phase III - Load Manual Data to Production & 10 & 36,940 & 23FEB01 & 08MAR01 & । & Phase III - Load Manual Data to Production \\
\hline 71016685 & 03 & Phase III - Integration Application Testing & 12 & 45,044 & 23FEB01 & 12MAR01 & 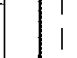 & Phase III - Integration Application Testing \\
\hline 71016690 & 03 & Phase III - Security Definitions Profile & 5 & 13,612 & $27 M A R 01$ & 02APR01 & i & Phase III - Security Definitions Profile \\
\hline 71016695 & 03 & Phase III - Test Security & 3 & 7,988 & 03APR01 & 05APR01 & | & Phase |l1 - Test Security \\
\hline 71016700 & 03 & Phase III - Load Data To Test & 4 & 4,904 & 03APR01 & 06APR01 & 1 & Phase III - Lpad Data To Test \\
\hline 71016705 & 03 & Phase III - Implement New Work Processes & 10 & 33,860 & 09APR01 & 20APR01 & 1 & Phase III - Implement New Work Processes \\
\hline 71016710 & 03 & $\begin{array}{l}\text { Phase 1II - Integration and Configuration } \\
\text { Testin }\end{array}$ & 3 & 13,257 & 23APR01 & 25APR01 & 1 & Phase III \{Integration and Configuration Testin \\
\hline 71016715 & 03 & Phase III - Load Static Data to Production & 3 & 6,496 & 26APR01 & 30APR01 & i & Phase III - Load Static Data to Production \\
\hline 71016720 & 03 & $\begin{array}{l}\text { Phase III - Correct Process Based On } \\
\text { Findings }\end{array}$ & 2 & 5,708 & $01 \mathrm{MAY} 01$ & $02 M A Y 01$ & 1 & Phase III 1 Correct Process Based On Findings \\
\hline 71016725 & 03 & Phase III - Load Active Data to Production & 1 & 5,023 & 01 MAY01 & 01 MAY01 & $\begin{array}{l}1 \\
1\end{array}$ & Phaşe III - Load Active Dąta to Production \\
\hline 71016730 & 03 & Phase III - Performance Tuning & 10 & 5,222 & O3MAY01 & 16MAY01 & 1 & I Phase III - Performance Tuning \\
\hline 71016735 & 03 & $\begin{array}{l}\text { Phase IIt - Load Acceptance Region \& } \\
\text { Verify }\end{array}$ & 5 & 2,611 & 03MAY01 & O9MAY01 & 1 & Phase III - Load Acceptance Region \& Verify \\
\hline 71016740 & 03 & Phase III - Stress Testing & 5 & 5,222 & 03 MAY01 & O9MAY01 & 1 & Phase III - Streș Testing \\
\hline 71016745 & 03 & Phase III - Quality Assessment Go No-Go & 8 & 30,521 & 03MAY01 & 14MAY01 & 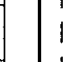 & Phase III - Quality Assessment Go No-Go \\
\hline 71016750 & 03 & Phase III - Passport Patrol Training & 5 & 14,484 & 03MAY01 & O9MAY01 & $\begin{array}{l}1 \\
1\end{array}$ & | Phase Ifl - Passport Patro| Training \\
\hline 71016755 & 03 & Phase III - Production Cut-over & 1 & 1,730 & 15MAY01 & 15MAY01 & । & Phase III - Production Cut-over \\
\hline
\end{tabular}


HNF-4244, Rev. 0

\begin{tabular}{|c|c|c|c|c|c|c|c|c|c|c|}
\hline Activity & Funding & Activity & Orig & Budgeted & Early & Early & & & & \\
\hline ID & Year & \begin{tabular}{|l} 
Description \\
\end{tabular} & Dur & Cost & Start & Finish & \begin{tabular}{|l|}
1998 \\
\end{tabular} & 1999 & 工 & 2001 \\
\hline 71016760 & 03 & Phase III - Issue Procedures & 3 & 1,158 & 16MAY01 & 18MAY01 & 1 & & I & Phase III - Issue Procedure \\
\hline 71016765 & 03 & Phase III - Operations & 16 & 174,503 & 18MAY01 & 11JUN01 & 1 & & i & Phas'e III - Operations \\
\hline 71016770 & 03 & Phase III - Operation Assessment & 2 & 9,439 & 12JUN01 & 13JUN01 & l & & I & Phase III - Operation Assessment \\
\hline
\end{tabular}

